\title{
Relationship between the Altaic Languages and the Korean Language
}

\author{
Mirae $\mathrm{Kim}^{1}$ and Andrew MacNeill ${ }^{2}$ \\ ${ }^{1}$ Davis Senior High School, Davis, CA, USA \\ ${ }^{2}$ Cobequid Educational Centre, Truro, NS, Canada
}

\begin{abstract}
Over the years, many Asian and Altaic linguists have argued about whether the Korean language belongs to the Altaic family. This research gives evidence that Korean, Japanese, and the Altaic languages including Turkic, Mongolic, and Tungusic share unique characteristics in vocabularies, sentence structure, and sound. It not only proposes the concept of such languages, but also explains how linguists have attempted to define the idea, and what more needs to be clarified for the Altaic Theory to be factual.
\end{abstract}

\section{Introduction}

The Korean language is a part of Altaic languages, due to their common characteristics of grammar, sound, and history. The Altaic languages are from the branches of Turkish, Mongolic and Tungusic officially. Korean and Japanese are often considered as a part of Altaic family, but it is still on discussing. This linguistic discussion is now becoming a theory. Linguists have worked for a long period of time to determine the answer of the Altaic Theory but have not yet unraveled the question. However, there are sufficient amount of evidence to prove that Korean is a part of Altaic language family. There is adequate information to determine that the Japanese language is analogous to the Altaic languages, as that helps linguists to recognize the similarities between Korean, Japanese, and the Altaic languages. Linguistic and historical features of these languages surely demonstrate analogue relationships.

Russian historical linguist Sergei Starostin published an academic paper about Altaic languages including Korean and Japanese in 2003, An Etymological Dictionary of Altaic Languages. The paper is written for academic purpose, for linguists and comparatists. Starostin included great number of detailed examples in phonology and morphology with further descriptions and explanations. However, it is hard to call it as a paper all about Altaic languages, as there are missing topics that could have explained the Altaic theory clearer, such as sound correspondences and difference between the languages.

According to the Altaic Theory, the Altaic languages and the Korean language share salient characteristics in grammar, such as consonants, sentence structure, morphology, and agglutination.

The Korean language have fourteen basic consonants in total. The Altaic consonants are all matching with Korean, except for one. $\bar{c}$, a Korean consonant with a sound of $\mathrm{h}$, is missing in the records of Korean-Altaic consonant. Linguists believe that $\div$ was derived from an Altaic consonant s. 해[hae], Korean word for sun, is called $s^{\vee} u n$ in

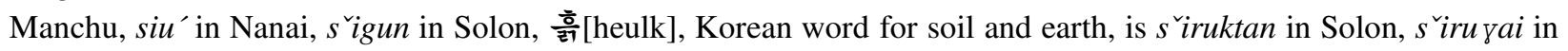
Mongolian (Lee and Ramsey 21). Also, in use of liquid consonants, Altaic languages and the Korean language tend to show similar vocabulary patterns. The examples below are from Lee and Ramsey. 


\begin{tabular}{|c|c|c|c|c|}
\hline English Word & Middle Korean & Similar Altaic (1) & Similar Altaic (2) & Similar Altaic(3) \\
\hline snowstorm & 눈보라 noonbora & boro'an(Mongolian) & burxan(Yakut) & \\
\hline $\begin{array}{c}\text { Ridge between } \\
\text { fields }\end{array}$ & 이랑 irang & iray̧a(Mongolian) & Irun(Manchu) & "1zan(Tatar) \\
\hline Lower part & 아래 alay & Alas(Evenki) & Ala(Mongolian) & $\mathrm{Al}$ (Old Turkic) \\
\hline
\end{tabular}

(Lee and Ramsey 21)

The second characteristic that Korean and the Altaic languages have is their sentence structure. Korean, Turkic languages, Manchu, Mongolian, and even Japanese all have SOV sentence structure (Kanazawa 21). Subject-ObjectVerb structure is used in the Altaic languages. Many Altaicists view that as a feature of Altaic languages have in common.

Specific morphological elements that the languages have in common set the baseline of Altaic Theory. Starostin (2003) gave numerous examples of Proto-Altaic derivational suffixes, including b, p ', m, d, t, t' , kt ' , n, l, r, č ' , ž, l, ́́, j, s, $\mathrm{g}, \mathrm{k}, \mathrm{k}$ ' and $\mathrm{y}$. Most of the cases are deverbative or denominative, and plenty of them are nominal suffixes (Starostin 22).

\begin{tabular}{|c|c|c|c|c|}
\hline Suffix & Proto Altaic & Defin. in Eng. & Example & Example \\
\hline $\mathrm{b}$ & dure & To burn, set fire & Dür-be (PM) & Dobu (Man) \\
\hline $\mathrm{p}$ & piubi & To mince, saw & Pubu (PTM) & Piwa (PJ) \\
\hline Ol,m & gằju & sorrow & kùjà-m (PJ) & kəi’ə-m (PK) \\
\hline $\mathrm{d}$ & ămV & quick, timely & am(a) (PTM) & am-亏̌i (PM) \\
\hline
\end{tabular}

Altaic, Japanese and Korean languages are all agglutinative in structure. Poppe defined agglutinative as inflection and word formation take place by adding of suffixes or endings (Poppe 189). Different languages have different structures, but Altaic languages tend to share common suffix functions. In Turkish, -e is a suffix with a function of dative. The word house in Turkish is ev. Eve with suffix -e means to the house. To form a plural meaning of house, it requires suffix -ler, so evler becomes a word meaning 'houses'. By using those two suffixes, the word evlere gets a meaning of 'to the houses'. Same things repeatedly occur in different Altaic languages also, such as in Manchu, Tungusic, and Korean. "To the houses" in Korean is 집 들로(jibdeulro). Base word house is 집(jib), with numeral suffix 들(deul) and a dating suffix 로(ro). Linguists have determined lots of comparing examples to prove that Altaic languages have common agglutinative features (Poppe 190).

Linguists can easily determine the relationship between the Altaic languages and the Korean language by using sound correspondences. Major common features occur in those languages are vowel harmony, nouns and verbs, phonology and phonetics.

Linguists discovered that the Altaic languages and the Korean language both have a system of their front vowels paired against back vowels, which linguists call 'vowel harmony' today. This occurs in Altaic languages and Uralic languages. According to Ramstedt, Korean suffix vowels are subjects of vowel harmony, such as a, e or o, u (Ramstedt 27). The stems are a and $\mathrm{o}$, and the back vowels are e and $u$. In Tungusic languages, $\ddot{o}$ and ü because they each developed into $u$ and $i$. Tungusic has lots of rules in vowel harmony. Such as after $\overline{0}, a / \bar{a}$ can be placed but not after o. After o, only o and $\bar{o}$ can be placed (Poppe 185).

The Altaic languages and the Korean language share similar nouns and verbs. In Mongolian and Turkic languages, there are very few homonymous verbs and nouns, and the same suffixes do not join verbal system and nominal system (Poppe 193). In Manchu-Tungus, suffixes taken my nominal stems do not join verbal system. In Korean, nominal stems do not work as verb, and verbal stems do not work as noun (Poppe 193).

The idea of phonology was used in 1440s to create the Korean language, like it was used in Altaic language as well. Starostin determined that "the most common root structure in Altaic languages is CVCV, occasionally with a 
medial consonant cluster CVCCV" (Starostin 22). Proto-Altaic was a pitch accent language, as today's Altaic languages are shown as monosyllabic (Starostin 23).

Comparatists study similarities of phonemes, accents, intonations, and rhythm patterns between the Altaic languages and the Korean language. There are correspondences on phonemes $\left(\mathrm{r}^{1}, \mathrm{r}^{2}, \mathrm{l}^{1}, \mathrm{l}^{2}\right)$ between Mongolic, Chuvash, Tungusic and Korean. In Proto-Altaic phonemes, it had shown linguists the same pattern as well. As Mongolic, Chuvash, Tungusic and Korean had two types of $r$ and two types of 1 , and Turkish had r, z, l, and š to replace, linguists made a group of corresponding phonemes; $\mathrm{r}^{1}, \mathrm{r}^{2}, 1^{1}$, and $\mathbf{1}^{2}$ (Georg et al 81).

The Altaic languages and the Korean language have lots of similarities based on their historical background. Manchu and Korea had long relationships over time in history. According to Lee and Ramsey, the Manchu people were the last Altaic conquerors of China and Korea and the rulers of the empire" (Lee and Ramsey 24). Back in prehistory, the ancestors of Korean people today migrated from Altaic area, from the north, through Siberia, Mongolia, Manchuria and China, and today historians can clearly see the interactions between Manchuria and Korea (Song 5).

Old Turkic nomadic confederations formed political, economic and militarise alliance with old Korean Kingdoms for over 2,000 years.

As Japanese is a part of the Altaic theory which is still being discussed, the Japanese and Korean languages share important features of languages. Japan and Korea both are two neighboring countries and interacted since prehistorical time. The two old Kingdoms shared culture, language, and goods (Kanazawa 3).

Although linguists can find similarities between the Altaic families, there are some problems such as lack of information about morphology, and not much specialists in all languages of Altaic theory. Most of the discussion on Altaic theory is concentrated in phonology and lexicon, but not morphology, which could be crucial in establishing the relationship between languages (Georg et al 84). Also, specialists in Korean and Japanese only write papers on these languages with no aspect of three Altaic languages, and Altaic controversy also focused on the possible relationships only between these three languages (Georg et al 72).

Although Altaic theory has issues such as lack of communications between the specialists, plenty evidences of Korean being a part of Altaic languages exist. As it is much easier today to research, find information, and acknowledge about foreign languages, linguists will repeatedly study about the Altaic Theory with more evidences. Due to their common characteristics of grammar, sound, and history, the Korean language is a part of Altaic languages.

\section{References}

Georg, Stefan, et al. "Telling General Linguists about Altaic.” Journal of Linguistics, 35.1(1999): 65-98. Cambridge University Press. Web. 1 March 1999.

Kanazawa, Shozaburo. The Common Origin of the Japanese and Korean Languages. Tokyo: Sanseido, 1910. Print.

Lee, Ki-Moon and Ramsey, S. Robert. A History of the Korean Language. New York:Cambridge University Press, 2011. Print.

Poppe, Nicholas. Introduction to Altaic Linguistics. Wiesbaden: Harrassowitz, 1965. Print.

Starostin S. A., Dybo A. V., Mudrak O. A. An Etymology Dictionary of Altaic Languages.Leiden: Brill Academic Pub, 2003. Print.

Song, Jae Jung. The Korean Language: Structure, Use and Context. London: Routledge, 2006. Print. 